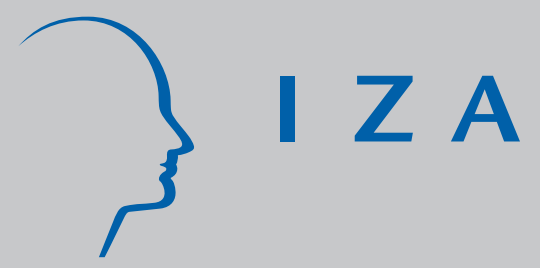

IZA DP No. 387

The Impact of Wage Increases on J ob Satisfaction - Empirical Evidence and Theoretical Implications

Christian Grund

Dirk Sliwka

November 2001 


\title{
The Impact of Wage Increases on Job Satisfaction - Empirical Evidence and Theoretical Implications
}

\author{
Christian Grund \\ University of Bonn and IZA, Bonn \\ Dirk Sliwka \\ University of Bonn
}

Discussion Paper No. 387

November 2001

\author{
IZA \\ P.O. Box 7240 \\ D-53072 Bonn \\ Germany \\ Tel.: +49-228-3894-0 \\ Fax: +49-228-3894-210 \\ Email: iza@iza.org
}

This Discussion Paper is issued within the framework of IZA's research area Mobility and Flexibility of Labor Markets. Any opinions expressed here are those of the author(s) and not those of the institute. Research disseminated by IZA may include views on policy, but the institute itself takes no institutional policy positions.

The Institute for the Study of Labor (IZA) in Bonn is a local and virtual international research center and a place of communication between science, politics and business. IZA is an independent, nonprofit limited liability company (Gesellschaft mit beschränkter Haftung) supported by the Deutsche Post AG. The center is associated with the University of Bonn and offers a stimulating research environment through its research networks, research support, and visitors and doctoral programs. IZA engages in (i) original and internationally competitive research in all fields of labor economics, (ii) development of policy concepts, and (iii) dissemination of research results and concepts to the interested public. The current research program deals with (1) mobility and flexibility of labor markets, (2) internationalization of labor markets and European integration, (3) the welfare state and labor markets, (4) labor markets in transition, (5) the future of work, (6) project evaluation and (7) general labor economics.

IZA Discussion Papers often represent preliminary work and are circulated to encourage discussion. Citation of such a paper should account for its provisional character. 
IZA Discussion Paper No. 387

November 2001

\section{ABSTRACT \\ The Impact of Wage Increases on Job Satisfaction - Empirical Evidence and Theoretical Implications}

The impact of wage increases on job satisfaction are explored. First, it is empirically established that current job satisfaction rises with absolute wage level as well as with wage increases. Second, a basic job satisfaction function is constructed based on the empirical results, and theoretical implications are analysed. It is shown that the myopic maximisation of such a function directly implies increasing and concave shaped age-earnings profiles.

JEL Classification: J28, J30, M12

Keywords: Job satisfaction, wage increases, habit formation, age-earnings profiles

Christian Grund

University of Bonn

Adenauer Allee 24-42

53113 Bonn

Germany

Tel.: +49228739213

Fax: +49228739210

Email: christian.grund@uni-bonn.de 


\section{Introduction}

Traditional economic theory assumes that the utility respectively the well being of a person depends on absolute consumption levels in all periods of the person's lifetime. Hence, the individual objective in most models requires the maximisation of the expected life time income, which determines directly the possible life time consumption paths. On the other hand, increased doubts are audible that this assumption is a good prediction for human behaviour. In a growing number of papers the assumption is made and evidence is found that utility is not only based on the absolute amount of income, but also on the relative level with respect to a certain reference point.

The idea that relative rather than absolute utility considerations are appropriate to describe and understand human decision making dates back to Markowitz (1952) and has found increasing empirical and theoretical support for instance in Kahneman and Tversky's Prospect Theory. ${ }^{1}$

In this paper we apply this idea to the analysis of job satisfaction and argue analogously that the perceived utility from a job does not only depend on the absolute wage, but also on wage increases. The wage of the last period acts as a reference point or an aspiration level. In a first step we start by empirically analysing determinants of job satisfaction as a proxy for the well being of employees concerning their work. We indeed find strong support for referencedependent preferences using data of the German Socio Economic Panel (GSOEP). Wage increases as well as the absolute level of wages have a significant positive impact on job satisfaction. A comparable empirical analysis has previously only been conducted by Clark (1999). Although Clark estimated a similar approach with British data, our results differ slightly from his with respect to the effect of the absolute wage level. However, we confirm the essential result that wage increases matter for employees' job satisfaction.

In a next step, we discuss a set of theoretical implications by including reference-dependent preferences into the utility function of employees. Based on our empirical observations we construct a job satisfaction function which is strictly increasing in the absolute wage level as well as in the wage increase an employee attains. We assume that an employee can exert

\footnotetext{
${ }^{1}$ Compare for instance Kahneman and Tversky (1979) or Tversky and Kahneman (1991).
} 
effort and that his current wage is an increasing function of his effort level. We then find that myopic maximisation of current job satisfaction has some interesting implications. First of all, an employee's current effort is strictly increasing in the wage level of the previous period. The higher the previous wage, the more effort the employee has to exert to attain a higher current wage as he enjoys wage increases. We then show that this leads to an increasing ageearnings profile: Although the employee's effort-wage relation remains constant, wages increase over time. In any period the employee tries to "beat" the standard set by the previous wage to achieve an additional wage increase. Furthermore, as additional wage increases are increasingly costly to achieve they are declining over time. Our simple model thus predicts that wages are upward sloping and concave in an employee's age.

Hence, we give a new explanation for the typical shape of age-earnings profiles as empirically observed in many studies. Previous explanations include human capital formation as stressed by Becker (1962) and the subsequent literature or moral hazard problems which lead to delayed wage payments as proposed by Lazear (1979). For a survey of the arguments see for instance Hutchens (1989).

Related to our theoretical results is a model by Frank and Hutchens (1993) where an individual's utility depends on consumption and on the growth rate of consumption. In their model, a situation is analyzed where an employee can distribute an exogenously given fixed amount of money across all periods of his life. They show that the agent will optimally choose an increasing consumption profile. However, they verbally refer to self control problems by the agent to explain increasing wage profiles. In contrast, our model explicitly analyses the effort an agent exerts to attain a certain wage level and does not take life-time wages as given.

A different strand of literature stresses the point that utility from consumption is not only affected by current consumption but also by agent's habits. This idea is mainly modelled by applying specific parameterised utility functions that are increasing in the ratio of current consumption to a habit stock, the latter being an increasing function of past consumption. ${ }^{2}$

\footnotetext{
${ }^{2}$ Contributions analysing different applications with specific utility functions are for instance Abel (1990) on asset pricing, Constantinides (1990) on the equity premium puzzle or recently Carroll et al. (2000), who show that with habit formation high growth rates lead to high savings.
} 
The particular assumptions of Prospect Theory are applied to a consumption savings problem in Bowman et al. (1999).

The paper proceeds as follows. In section 2 the empirical results are presented. In section 3 the simple theoretical model based on the empirical results is presented and its implications are analysed. A brief conclusion discusses other possible implications.

\section{Wages, Wage Increases, and Job Satisfaction - Empirical Evidence}

The considerations of the introduction lead to the presumption that the utility or well being of employees does not only depend on the absolute amount of their wages but also on wage increases, because people judge their utility with respect to a certain reference point or aspiration level, which is argued to be their wage of the prior period. ${ }^{3}$ Job satisfaction seems to be a reasonable proxy for the well being of employees with respect to their work (see Clark and Oswald 1996: 364). In some surveys people have to rank their job satisfaction by using an ordinal scale. Usually, this scale reaches from "totally unhappy with the job" (0) to "totally happy", which is equivalent with the value 7 at the British Household Panel Survey (BHPS) or 10 at the German Socio-Economic Panel (GSOEP), respectively.

There is only one prior study that analyses the impact of both wages and wage increases on job satisfaction explicitly. Clark (1999), using the first two waves of the BHPS, finds positive effects of both variables, but astonishingly no significant effect of the absolute amount of the wage alone. Few other studies deal with job satisfaction on the basis of the GSOEP in different ways. Clark et al. (1998) detect a positive link between job satisfaction and subsequent quits. Grund (2001: 212-220) concentrates on increases of job satisfaction after job changes and Matiaske and Mellewigt (2001) point out general decreasing job satisfaction in Germany since the mid eighties.

\footnotetext{
${ }^{3}$ Clark and Oswald (1996) use another possible reference point by estimating a comparison wage for each individual as a kind of aspiration level giving the average income of an employee having the same qualifications, age and so on against which the employees compare themselves. They show that indeed higher comp arison wages lead to lower job satisfaction.
} 
We use the data of the German Socio-Economic Panel (GSOEP), a large representative German survey, and concentrate on the data of 1995. Only in this year detailed information about the working conditions are inquired both for West- and East-German employees. ${ }^{4}$ Our sample is restricted to full time employees (blue collar and white collar workers), who are 20 to 60 years old and receive a gross monthly wage of at least DM $1,000^{5}$ in 1995 and 1994 . We need the 1994 wave of the GSOEP as well, because we want to analyse effects of wage increases. Due to these restrictions we get a sample size of 3,568 employees.

Within the GSOEP the respondents have to answer the question 'How satisfied are you with your job?" using a scale from 0 (totally unhappy) to 10 (totally happy). The distribution of the answers to this question are shown in Table 1 . Nearly half of the respondents state a job satisfaction of 8 or more. These people can be declared as very satisfied. The average level of job satisfaction is 6.97 .

Table 1: Frequencies of Job Satisfaction

\begin{tabular}{lccc}
\hline Job satisfaction & Frequency & Percent (\%) & Accumulated (\%) \\
\hline 0 (totally unhappy) & 19 & 0.5 & 0.5 \\
1 & 23 & 0.6 & 1.2 \\
2 & 78 & 2.2 & 3.4 \\
3 & 114 & 3.2 & 6.6 \\
4 & 142 & 4.0 & 10.5 \\
5 & 421 & 11.8 & 22.3 \\
6 & 416 & 11.7 & 34.0 \\
7 & 658 & 18.4 & 52.4 \\
8 & 974 & 27.3 & 79.7 \\
9 & 456 & 12.8 & 92.5 \\
10 (totally happy) & 267 & 7.5 & 100 \\
\hline$\Sigma$ & 3,568 & 100 & \\
\hline
\end{tabular}

We use monthly gross wages as our wage variable. There is a slight increase of the average wage from DM 3,924 German marks in 1994 to DM 4,106 in 1995 in our sample. Nearly two of three employees realise nominal wage increases and over $20 \%$ have to accept wage reductions from 1994 to 1995.

\footnotetext{
${ }^{4}$ However, the essential empirical results hold for the analysis of other years without the working conditions as well.

${ }^{5}$ All wages are given in German Mark (DM). A transformation in Euro can be made by a division by 1.95583.
} 
The focus of this empirical part is to investigate whether there is an effect of wage increases on job satisfaction. As a first indicator we examine the correlation coefficient between job satisfaction and wage increases, which are defined as the ratio of the current monthly gross wage and the monthly gross wage one year before. This correlation is significantly positive and the value (0.07) is not much smaller than the correlation between job satisfaction and the absolute amount of the wages (0.10). But there are other determinants of job satisfaction as well. For example, Wall et al. (1978) find a strong negative relationship between job satisfaction and poor mental health and Clark (1997) asks: Why are women so happy at work? The descriptive statistics of Table 2 show that there is a strong relationship between health and job satisfaction in our sample as well, but the average amount of job satisfaction is not much higher for women than for men in our German data.

Table 2: Descriptive statistics of gender and health status

\begin{tabular}{llll}
\hline & $\begin{array}{l}\text { Frequency } \\
(\%)\end{array}$ & $\begin{array}{l}\text { Average } \\
\text { job satisfaction }\end{array}$ & $\begin{array}{l}\text { Percent } \\
\text { "very satisfied" }\end{array}$ \\
\hline Overall & 100 & 6.97 & 47.6 \\
Men & 67.0 & 6,95 & 47.0 \\
Women & 33.0 & 7.00 & 48.7 \\
& & & 76.3 \\
Very good health & 9.3 & 8.17 & 54.9 \\
Good health & 48.8 & 7.33 & 35.3 \\
Satisfying health & 30.8 & 6.52 & 25.8 \\
Poor health & 9.6 & 5.63 & 18.9 \\
Very poor health & 1.5 & 5.28 & \\
Note: "very satisfied" is equivalent to a stated job satisfaction of at least 8 at the scale from 0 (totally unhappy to \\
10 (totally happy).
\end{tabular}

Table 3 shows the regression results. First, we regress only gender, health status dummies and the absolute wage on job satisfaction using the ordered probit approach, because job satisfaction is an ordinal variable. As can be directly seen wage is positively correlated with job satisfaction. This result supports traditional economic theory, but contradicts the result of Clark (1999) for the situation in Great Bitain. Controlling for the wage men are less satisfied with their work than women and the health status is strongly correlated with job satisfaction. These results are in accordance with prior results of Clark (1999) and Clark and Oswald (1996). 
In the second regression, we include the logarithm of the gross monthly wage one year ago. We expect that this variable is negatively correlated with job satisfaction. This approach has the following form:

$$
J_{o b} \text { Satisfaction }_{t}=\alpha \cdot \ln W A G E_{t}+\beta \cdot \ln W A G E_{t-1}+X,
$$

where $X$ describes the vector of the other independent variables. As can easily be seen after a small transformation, the effect of wage increases are measured directly with this approach:

$$
\text { Job Satisfaction }_{\mathrm{t}}=(\alpha+\beta) \cdot \ln W A G E_{t}-\beta \cdot\left[\ln \left(W A G E_{t} / W A G E_{t-1}\right)\right]+X .
$$

Hence, we expect a negative value for the estimated coefficient $\beta$ in this specification.

The results confirm our hypothesis. There is a positive effect on job satisfaction for the absolute wage as well as the wage increase. This result contradicts traditional economic theory, but is in line with the empirical study of Clark (1999).

In a next step, we enlarge our specification with a large set of possible additional determinants of job satisfaction. There are both demographic (e.g., age, education, foreign, marital status) as well as job based characteristics like industry, firm size, occupational status and especially several dummy variables for working conditions ${ }^{6}$ among them. The qualitative results with respect to the wage of both years are not affected by this specification with more explanatory variables. This result is robust with regard to other specifications with only part of the variables and to the subgroups of male and female employees. Also the liquidation of employees with extremely high wage increases and wage losses does not change the results. ${ }^{7}$ Hence, the empirical findings strongly support the hypothesis that both the absolute wage and wage increases affect job satisfaction positively. This observation leads to several economic implications, which we will present in the following section.

\footnotetext{
${ }^{6}$ This set of dummy variables controls for variation in work, physically demanding work, self-dependent work, variation of working hours, supervision of productivity, shift work, conflict with supervisors, relationship to coworkers, participation at promotion decisions, acquisition of useful skills, undesirable working conditions, mental strenuousness, and risk of work related accidents. People have to state whether these characteristics do not apply, partly apply, or fully apply in their jobs.

${ }^{7}$ There are seven employees with wage increases above $100 \%$ and eight employees with wage decreases of more than $50 \%$ without dramatic changes of the working hours in the sample. The t-statistics of both wage variables become even slightly larger without these outliers.
} 
Table 3: Ordered probit regression on job satisfaction

\begin{tabular}{|c|c|c|c|c|}
\hline & (1) & (2) & (3) & (4) \\
\hline Log current gross monthly wage & $\begin{array}{c}0.322 \\
(6.395)\end{array}$ & $\begin{array}{c}0.647 \\
(5.415)\end{array}$ & $\begin{array}{c}0.407 \\
(4.841)\end{array}$ & $\begin{array}{c}0.649 \\
(4.923)\end{array}$ \\
\hline Log gross monthly wage one year ago & & $\begin{array}{l}-0.348 \\
(2.997)\end{array}$ & & $\begin{array}{l}-0.295 \\
(2.386)\end{array}$ \\
\hline Male & $\begin{array}{l}-0.126 \\
(3.322)\end{array}$ & $\begin{array}{l}-0.116 \\
(3.048)\end{array}$ & $\begin{array}{l}-0.078 \\
(1.593)\end{array}$ & $\begin{array}{c}-0.067 \\
(1.347))\end{array}$ \\
\hline Health very good & $\begin{array}{c}1.017 \\
(15.40)\end{array}$ & $\begin{array}{c}1.011 \\
(15.30)\end{array}$ & $\begin{array}{c}0.913 \\
(13.07)\end{array}$ & $\begin{array}{c}0.911 \\
(13.04)\end{array}$ \\
\hline Health good & $\begin{array}{c}0.430 \\
(10.85)\end{array}$ & $\begin{array}{c}0.429 \\
(10.83)\end{array}$ & $\begin{array}{c}0.368 \\
(8.916)\end{array}$ & $\begin{array}{c}0.368 \\
(8.921)\end{array}$ \\
\hline Health poor & $\begin{array}{l}-0.409 \\
(6.466)\end{array}$ & $\begin{array}{l}-0.406 \\
(6.421)\end{array}$ & $\begin{array}{l}-0.324 \\
(4.988)\end{array}$ & $\begin{array}{l}-0.324 \\
(4.979)\end{array}$ \\
\hline Health very poor & $\begin{array}{l}-0.548 \\
(3.830)\end{array}$ & $\begin{array}{l}-0.536 \\
(3.743)\end{array}$ & $\begin{array}{l}-0.416 \\
(2.825)\end{array}$ & $\begin{array}{l}-0.412 \\
(2.793)\end{array}$ \\
\hline Log current weekly working hours & & & $\begin{array}{c}0.134 \\
(0.653)\end{array}$ & $\begin{array}{c}0.108 \\
(0.524)\end{array}$ \\
\hline Log weekly working hours one year ago & & & $\begin{array}{l}-0.214 \\
(1.085)\end{array}$ & $\begin{array}{l}-0.153 \\
(0.442)\end{array}$ \\
\hline $\begin{array}{l}\text { Difference between actual and preferred working } \\
\text { hours }\end{array}$ & & & $\begin{array}{l}-0.004 \\
(1.891)\end{array}$ & $\begin{array}{l}-0.004 \\
(1.954)\end{array}$ \\
\hline Age & & & $\begin{array}{l}-0.020 \\
(1.225)\end{array}$ & $\begin{array}{l}-0.016 \\
(0.985)\end{array}$ \\
\hline Age-squared $(* 100)$ & & & $\begin{array}{c}0.022 \\
(1.126)\end{array}$ & $\begin{array}{c}0.018 \\
(0.918)\end{array}$ \\
\hline Years of schooling & & & $\begin{array}{l}-0.051 \\
(5.162)\end{array}$ & $\begin{array}{l}-0.051 \\
(5.137)\end{array}$ \\
\hline Foreign & & & $\begin{array}{c}0.106 \\
(1.862)\end{array}$ & $\begin{array}{c}0.107 \\
(1.882)\end{array}$ \\
\hline Immigrant & & & $\begin{array}{c}0.185 \\
(2.007)\end{array}$ & $\begin{array}{c}0.181 \\
(1.960)\end{array}$ \\
\hline Quit one year ago & & & $\begin{array}{c}0.223 \\
(2.235)\end{array}$ & $\begin{array}{c}0.206 \\
(2.063)\end{array}$ \\
\hline Dismissal one year ago & & & $\begin{array}{c}-0.133 \\
(1.049)\end{array}$ & $\begin{array}{l}-0.107 \\
(0.838)\end{array}$ \\
\hline Self initiated intra-firm job change one year ago & & & $\begin{array}{c}0.394 \\
(1.516)\end{array}$ & $\begin{array}{c}0.393 \\
(1.510)\end{array}$ \\
\hline Firm initiated intra-firm job change one year ago & & & $\begin{array}{l}-0.291 \\
(0.913)\end{array}$ & $\begin{array}{l}-0.298 \\
(0.937)\end{array}$ \\
\hline Marital status dummies (6) & No & No & Yes & Yes \\
\hline Region dummies (16) & No & No & Yes & Yes \\
\hline Industry dummies (36) & No & No & Yes & Yes \\
\hline Firm size dummies (5) & No & No & Yes & Yes \\
\hline Working condition dummies $(2 * 13)$ & No & No & Yes & Yes \\
\hline Occupational status dummies (11) & No & No & Yes & Yes \\
\hline Observations & 3568 & 3568 & 3568 & 3568 \\
\hline Log-Likelihood & -6915.1 & -6910.6 & -6607.9 & -6605.1 \\
\hline Pseudo- $R^{2}$ & 0.035 & 0.036 & 0.078 & 0.078 \\
\hline
\end{tabular}

Note: Absolute T-values in parentheses. 
The results with regard to the other variables are interesting as well, but less decisive for our study. Job satisfaction roughly depends on preferences and aspirations of employees concerning their jobs. Aspirations are increasing with education for example. Thus, we find a negative effect for years of schooling. Additionally, preferences, which are not satisfied, lead to a lower job satisfaction. See, for example, the negative coefficient of the difference between actual and aspired working hours. There are also some significant negative effects of working conditions like supervision, conflicts with supervisors, and mental strenuous work.

\section{Theoretical Implications}

In this section we set up a work satisfaction function with the properties estabilished in the previous section and analyse the theoretical implications. Most importantly, we will show that under quite general assumptions myopic maximisation of current work satisfaction straigtforwardly leads to increasing and concave age-earnings profiles in a stationary environment even in the absense of human capital formation and without referring to bonding and similar issues.

\subsection{A Simple Model}

To study some theoretical implications of the previous considerations we introduce a simple model. We make the key assumption that in each period an employee myopically maximises his current job satisfaction. We intentionally depart from a dynamic optimisation standpoint as for instance applied in Bowman, Minehart and Rabin (1999) or Frank and Hutchens (1993). A dynamically optimising agent with reference based utility will for instance undertake less wage increasing activities as he is anticipating that a too high wage increase today will make it harder to achieve a wage increase tomorrow. It seems to us at least doubtful whether such behaviour is plausible and, as a consequence, that dynamic optimisation and reference point relatedness are compatible from a descriptive rather than normative point of view.

We state a basic job satisfaction function, which according to our empirical results is strictly increasing in the current absolute wage $w_{t}$ and the difference between the actual wage and the last period wage denoted by $\Delta w_{t}$. Furthermore, we assume that in each period the employee can undertake activities that affect his current wage. We denote the level of wage increasing 
activities in period $t$ by $e_{t} \in R_{0}^{+}$. When the employee attains a wage $w$, a wage increase of $\Delta w$ and exerts an effort level $e$ in a certain period, his current job satisfaction is given by ${ }^{8}$

$$
s(w, \Delta w, e),
$$

where the wage increase in a period $t$ is given by

$$
\Delta w_{t}=w_{t}-w_{t-1} .
$$

The variable $e$ may for instance encompass the effort exerted to receive a higher bonus payment or to win an internal promotion tournament or any expenses made to find a new and better paid job. We assume that wage is an increasing and strictly concave function of the worker's effort $e$ :

$$
w=w(e) \text { where } \frac{\partial w(e)}{\partial e}>0 \text { and } \frac{\partial^{2} w(e)}{\partial e^{2}}<0 .
$$

It is important to note that we assume a time invariant wage function. This implies that to achieve a certain wage level at any point in an employee's career he has to exert the same effort level. That may be surprising at first glance as one may think that after having achieved a promotion, an employee may be able to keep the same wage with a lower effort in the consecutive period. But it may well be argued, that the promotion brings about more responsibility and that the employee needs to exert at least as much effort as before the promotion has taken place. However, it will become clear that dropping this assumption should only strengthen our results as it will lead to steeper age-earnings profiles.

For simplicity we assume additive separability of the work satisfaction function, in satisfaction arising from wages and wage increases on the one hand and the costs of effort on the other:

$$
s(w, \Delta w, e)=v(w, \Delta w)-c(e) .
$$

Work satisfaction is is strictly increasing in $w$ and $\Delta w$, the cost function strictly increasing in the effort level. In addition we impose the following assumptions:

$$
\frac{\partial^{2} c(e)}{\partial e^{2}}>0, \frac{\partial^{2} v(w, \Delta w)}{\partial w^{2}}<0 \text { and } \frac{\partial^{2} v(w, \Delta w)}{\partial \Delta w^{2}}<0 .
$$

\footnotetext{
${ }^{8}$ Note that such a function can of course be easily transformed to the form $u\left(w_{t}, w_{t-1}, e_{t}\right)$ that has been analysed in the empirical part of this paper. The first derivative of the transformed function with respect to $w_{t-1}$ yields a negative sign as has been shown in the empirical investigation. However, it has turned out that the formulation given here simplifies the exposition of the theoretical results.
} 
Hence, the costs of wage raising activities are strictly convex and the marginal impacts of wages and wage increases on work satisfaction are decreasing. Finally, we assume that the marginal work satisfaction of a wage increase is decreasing in the wage level

$$
\frac{\partial^{2} v(w, \Delta w)}{\partial w \partial \Delta w}<0
$$

Recall that $\Delta w$ measures the absolute and not the relative wage increase. Hence, it is natural to assume that raising a wage for someone who is earning $1000 \$$ a month by $100 \$$ increases his satisfaction in a stronger way than raising the wage of someone who is earning $10000 \$$ by the same amount.

\subsection{Age-Earnings Profiles}

To examine the implications of such a work satisfaction function, we inspect the optimisation problem of an employee in a given period $t$ :

$$
\begin{aligned}
& \max _{e, w_{t}} v\left(w_{t}, w_{t}-w_{t-1}\right)-c\left(e_{t}\right) \\
& \text { s.t. } w_{t}=w\left(e_{t}\right)
\end{aligned}
$$

As a reference case, first consider a situation where $\Delta w_{t}$ does not enter the job satisfaction function. Then of course the optimisation problem is independent from the previous wage and hence, identical in all periods. The agent would choose a constant optimal value of $e_{t}$ and thus obtain a constant wage level across all periods of the working life.

If, however, as we have shown in Section 2 and stated in the assumptions of the model $\Delta w_{t}$ enters the job satisfaction function a different picture arises as we will see in this section. By substituting $w_{t}=w\left(e_{t}\right)$ in the optimisation problem and taking the first derivative we obtain the following first order condition:

$$
\left(\frac{\partial v\left(w\left(e_{t}\right), w\left(e_{t}\right)-w_{t-1}\right)}{\partial w}+\frac{\partial v\left(w\left(e_{t}\right), w\left(e_{t}\right)-w_{t-1}\right)}{\partial \Delta w}\right) \frac{\partial w\left(e_{t}\right)}{\partial e}-\frac{\partial c\left(e_{t}\right)}{\partial e}=0
$$

As can be easily verified, the optimisation problem is strictly concave. Hence, Equation (3) defines a unique value of $e_{t}$. The optimal effort level is attained when marginal "gross" job satisfaction is equal to marginal costs of effort. This expression implicitly defines the current effort $e_{t}$ as a function of the previous wage $w_{t-1}$. To analyse the effect of the previous wage 
on the worker's effort choice and, hence, on his current wage, we implicitly differentiate this condition and compute $\partial e_{t} / \partial w_{t-1}$. We obtain the following result:

Lemma 1: An employee's effort and his current wage are strictly increasing in the previous wage.

Proof: See Appendix.

In addition to the absolute wage level, the employee enjoys wage increases above the previous wage. The higher the reference standard defined by the previous wage, the harder the employee has to work to achieve the additional satisfaction from beating this standard. From a more technical point of view, note that a higher value of $w_{t-1}$ reduces the size of the wage increase $\Delta w_{t}$ achieved with a given effort level. Due to the concavity of the work satisfaction function a higher previous wage raises the marginal impact of $\Delta w_{t}$ and thus the marginal return of effort for any value of $e_{t}$. Hence, in the optimum the agent will choose a higher effort level. As the current wage is a monotonically increasing function of $e_{t}$, it is of course also increasing in the previous wage.

This result gives us a positive relationship between wages in consecutive periods. It is now interesting to check whether something can be said about the slope of the earnings profile. Hence, we examine whether $w_{t}$ monotonically changes over time. Indeed we get the following result:

Proposition 1: If an employee starts his career with a positive wage level, wages strictly increase over time.

Proof: See Appendix.

A kind of "ratchet effect" exists. The higher the wage an agent attained in the previous period, the higher is the reference standard at which he evaluates current job satisfaction.

\footnotetext{
${ }^{9}$ This of course should not be confounded with the ratchet effect in incentive theory.
} 
Satisfaction due to a wage increase can only be achieved by exerting even more effort than in the previous period.

To understand this result, it is important to note that the marginal impact of effort on the employee's well beeing in a certain period is higher than in the preceding period if he chooses the same effort level in both periods. Therefore effort levels have to increase over time. The former is due to two effects: First, with a constant effort level, $\Delta w$ has a value of zero and due to the decreasing marginal returns its marginal impact on job satisfaction is higher in the current period if there has previously been a strictly positive wage increase. But in addition, the marginal job satisfaction from the absolute wage level is also higher as absolute wage and wage increase are substitutes in generating job satisfaction. ${ }^{10}$

Hence, the current wage the employee attains will always exceed the previous wage if the worker's career starts with in initial wage increase, which is trivially the case as getting a wage in a first job of course comes along with a wage increase. We have shown that earnings profiles are indeed upward sloping. Finally, we examine wether our simple model yields some results on the shape of age-earnings profiles.

Proposition 2: The wage increases $\Delta w_{t}$ decrease over time.

Proof: See Appendix.

In the previous result, we have shown that effort levels and wages raise over time. But of course attaining further wage increases becomes more and more costly, as the marginal costs of effort increase with the effort level due to the convexity of the cost function. Therefore, the size of attained wage increases gets weaker over time. Hence, our simple model implies concave shaped age-earnings profiles, which are empirically well known.

\footnotetext{
${ }^{10}$ As another consequence, job satisfaction declines if a wage increase fails to appear in one period for instance because of an exogenous shock. However, if the employee realised constant wages during more than two periods he would "get used" to missing wage increases and his job satisfaction would be constant.
} 


\section{Conclusion}

Our empirical investigation confirmed that job satisfaction strongly depends on the relative wage increase as well as the absolute wage level. We have then built a simple model encompassing a job satisfaction function that reflects such preferences. The myopic maximisation of job satisfaction leads indeed to increasing and concave age-earnings profiles. An agent works harder when a previous wage has been higher as a wage increase in itself yields additional utility.

Of course, we have abstracted from many factors affecting age-earnings profiles that are of importance in reality such as human capital formation, moral hazard problems, promotions to different jobs and so on. However, the omission of those factors strengthens our key point: Wages raise over time even in an otherwise completely stationary constant environment simply because employees enjoy attaining increasing wages.

There are many other research questions in labour economics that might be addressed fruitfully applying reference point related utility functions. For instance, wage increase dependent well being might be another explanation for fast track effects ${ }^{11}$ in employees' careers without any necessity of information effects or ex ante heterogeneous individuals. Employees who receive high wage increases or promotions early in their career form higher reference points or aspiration levels and, hence, work harder as compared to workers without these early successes in their occupational careers to keep up with such a standard. This should in turn lead again to quicker promotions and so on.

Further on, it seems interesting to look at incentive contracts in the light of such behaviour. If an agent's compensation depends on his performance, this nearly always entails uncertainty as is well understood in agency theory. However, income uncertainty comes along with the possibility of income losses relative to the previous period. The kind of job satisfaction utility function suggested in this paper then leads to a double loss in the agent's well being: First, of course as his absolute income level is lower. But in addition his satisfaction is further

\footnotetext{
${ }^{11}$ Fast track effects within a firm are observable if quickly promoted employees are promoted quickly at the next level of the hierarchy as well. For theoretical explanations of and empirical evidence for fast track promotions see e.g., Rosenbaum (1979), Pucik (1991), Baker et al. (1994), and Kräkel (1994). See Chiappori et al. (1999) for a corresponding "late beginner effect".
} 
decreased due to the relative loss. This observation might help to understand why incentive contracts are much less observed in practice than suggested by standard agency theory. 


\section{Appendix}

\section{Proof of Lemma 1:}

$$
\begin{gathered}
\frac{\partial e_{t}}{\partial w_{t-1}}=-\frac{\left(\frac{\partial^{2} v}{\partial w \partial \Delta w}(-1)+\frac{\partial^{2} v}{\partial \Delta w^{2}}(-1)\right) \frac{\partial w}{\partial e}}{\left(\frac{\partial^{2} v}{\partial w^{2}} \frac{\partial w}{\partial e}+\frac{\partial^{2} v}{\partial w \partial \Delta w} \frac{\partial w}{\partial e}+\frac{\partial v}{\partial \Delta w \partial w} \frac{\partial w}{\partial e}+\frac{\partial^{2} v}{\partial \Delta w^{2}} \frac{\partial w}{\partial e}\right) \frac{\partial w}{\partial e}+\left(\frac{\partial v}{\partial w}+\frac{\partial v}{\partial \Delta w}\right) \frac{\partial^{2} w}{\partial e^{2}}-\frac{\partial^{2} c}{\partial e^{2}}} \\
=\frac{\left(\frac{\partial^{2} v}{\partial w \partial \Delta w}+\frac{\partial^{2} v}{\partial \Delta w^{2}}\right) \frac{\partial w}{\partial e}}{\left(\frac{\partial^{2} v}{\partial w^{2}}+\frac{2 \partial^{2} v}{\partial w \partial \Delta w}+\frac{\partial^{2} v}{\partial \Delta w^{2}}\right)\left(\frac{\partial w}{\partial e}\right)^{2}+\left(\frac{\partial v}{\partial w}+\frac{\partial v}{\partial \Delta w}\right) \frac{\partial^{2} w}{\partial e^{2}}-\frac{\partial^{2} c}{\partial e^{2}}}
\end{gathered}
$$

The sign of this expression is positive:

$$
\frac{((-)+(-))(+)}{((-)+(-)+(-))(+)+((+)+(+))(-)(+)}=\frac{(-)}{(-)}=(+)
$$

The positive relation between the current and previous wage follows directly as $w_{t}=w\left(e_{t}\right)$ is strictly increasing in $e_{t}$.

\section{Proof of Proposition 1:}

Suppose that indeed $e_{t+1}>e_{t}$. As $s($.$) is strictly concave in e_{t}$ a sufficient condition for this is that

$$
\left.\frac{\partial s_{t+1}}{\partial e_{t+1}}\right|_{e_{t+1}=e_{t}}>0
$$

We know that in period $t$ the following first order condition must hold

$$
\left(\frac{\partial v\left(w_{t}, \Delta w_{t}\right)}{\partial w}+\frac{\partial v\left(w_{t}, \Delta w_{t}\right)}{\partial \Delta w}\right) \frac{\partial w\left(e_{t}\right)}{\partial e}-\frac{\partial c\left(e_{t}\right)}{\partial e}=0 .
$$

Now we examine the first derivative of the work satisfaction function with respect to the employee's effort in the next period $t+1$ :

$$
\frac{\partial s_{t+1}}{\partial e_{t+1}}=\left(\frac{\partial v\left(w\left(e_{t+1}\right), \Delta w_{t+1}\left(e_{t+1}\right)\right)}{\partial w}+\frac{\partial v\left(w\left(e_{t+1}\right), \Delta w_{t+1}\left(e_{t+1}\right)\right)}{\partial \Delta w}\right) \frac{\partial w\left(e_{t+1}\right)}{\partial e}-\frac{\partial c\left(e_{t+1}\right)}{\partial e}
$$

But if $e_{t+1}=e_{t}$ we have that $w_{t+1}=w_{t}$ and therefore $\Delta w_{t+1}=0$, hence,

$$
\frac{\partial s_{t+1}}{\partial e_{t+1}}=\left(\frac{\partial v\left(w\left(e_{t}\right), 0\right)}{\partial w}+\frac{\partial v\left(w\left(e_{t}\right), 0\right)}{\partial \Delta w}\right) \frac{\partial w\left(e_{t}\right)}{\partial e}-\frac{\partial c\left(e_{t}\right)}{\partial e}
$$

As 


$$
\left(\frac{\partial v\left(w\left(e_{t}\right), 0\right)}{\partial w}+\frac{\partial v\left(w\left(e_{t}\right), 0\right)}{\partial \Delta w}\right)>\left(\frac{\partial v\left(w_{t}, \Delta w_{t}\right)}{\partial w}+\frac{\partial v\left(w_{t}, \Delta w_{t}\right)}{\partial \Delta w}\right)
$$

for $\Delta w_{t}>0$ we must indeed have that

$$
\left.\frac{\partial u_{t+1}}{\partial e_{t+1}}\right|_{e_{t+1}=e_{t}}>0
$$

If the employee started his career with a positive wage level, it is clearly the case that in the first period $\Delta w>0$. As we have shown this carries over to all consecutive periods.

\section{Proof of Proposition 2:}

We know that wages increase over time. Hence, it suffices to establish the relationship between $\Delta w_{t}=w\left(e_{t}\right)-w_{t-1}$ and $w_{t-1}$. First, note that

$$
\frac{\partial \Delta w}{\partial w_{t-1}}=\frac{\partial w}{\partial w_{t-1}}-1
$$

But,

$$
\frac{\partial w}{\partial w_{t-1}}=\frac{\partial w}{\partial e} \frac{\partial e}{\partial w_{t-1}} .
$$

In Lemma 1 we have computed $\partial e / \partial w_{t-1}$. We can use this to get

$$
\begin{aligned}
\frac{\partial w}{\partial w_{t-1}} & =\frac{\partial w}{\partial e} \frac{\left(\frac{\partial^{2} v}{\partial w \partial \Delta w}+\frac{\partial^{2} v}{\partial \Delta w^{2}}\right) \frac{\partial w}{\partial e}}{\left(\frac{\partial^{2} v}{\partial w^{2}}+\frac{2 \partial^{2} v}{\partial w \partial \Delta w}+\frac{\partial^{2} v}{\partial \Delta w^{2}}\right)\left(\frac{\partial w}{\partial e}\right)^{2}+\left(\frac{\partial v}{\partial w}+\frac{\partial v}{\partial \Delta w}\right) \frac{\partial^{2} w}{\partial e^{2}}-\frac{\partial^{2} c}{\partial e^{2}}}-1 \\
& =\frac{\left(-\frac{\partial^{2} v}{\partial w^{2}}-\frac{\partial^{2} v}{\partial w \partial \Delta w}\right)\left(\frac{\partial w}{\partial e}\right)^{2}\left(\frac{\partial v}{\partial w}+\frac{\partial v}{\partial \Delta w}\right) \frac{\partial^{2} w}{\partial e^{2}}+\frac{\partial^{2} c}{\partial e^{2}}}{\left(\frac{\partial^{2} v}{\partial w^{2}}+\frac{2 \partial^{2} v}{\partial w \partial \Delta w}+\frac{\partial^{2} v}{\partial \Delta w^{2}}\right)\left(\frac{\partial w}{\partial e}\right)^{2}+\left(\frac{\partial v}{\partial w}+\frac{\partial v}{\partial \Delta w}\right) \frac{\partial^{2} w}{\partial e^{2}}-\frac{\partial^{2} c}{\partial e^{2}}}
\end{aligned}
$$

Checking the signs, we get

$$
\frac{(-(-)-(-))(+)-((+)+(+))(-)+(+)}{((-)+(-)+(-))(+)+((+)+(+))(-)-(+)}=\frac{(+)}{(-)}=(-)
$$

Indeed, we can conclude that

$$
\frac{\partial \Delta w}{\partial w_{t-1}}<0
$$

i.e. wage increases get smaller over time. 


\section{References}

Abel, A.B. (1990): Asset Prices under Habit Formation and Catching Up with the Joneses. American Economic Review 80, 38-42.

Baker, G.; M. Gibbs; B. Holmstrom (1994): The Internal Economics of the Firm: Evidence from Personnel Data. Quarterly Journal of Economics 109, 881-919.

Becker, G.S. (1962): Investment in Human Capital: A Theoretical Analysis, Journal of Political Economy. 70, 9-49.

Bowman, D.; D. Minehart; M. Rabin (1999): Loss Aversion in a Consumption-Savings Model. Journal of Economic Behavior \& Organization 39, 155-178.

Carrol, C. D.; J. Overland; D.N. Weil (2000): Saving and Growth with Habit Formation. American Economic Review 90, 341-355.

Chiappori, P.A.; B. Salanie; J. Valentin (1999): Early Starters Versus Late Beginners. Journal of Political Economy 107, 731-760.

Clark, A.E. (1996): Job Satisfaction in Britain. British Journal of Industrial Relations 34, 189217.

Clark, A.E. (1997): Job Satisfaction and Gender: Why are Women so Happy at Work? Labour Economics 4, 341-372.

Clark, A.E. (1999): Are wages habit-forming? Evidence from micro data. Journal of Economic Behavior \& Organization 39, 179-200.

Clark, A.E.; A.J. Oswald (1996): Satisfaction and Comparison Income. Journal of Public Economics 61, 359-381.

Clark, A.E.; Y. Georgellis; P. Sanfey (1998): Job Satisfaction, Wage Changes, and Quits: Evidence from Germany. Research in Labor Economics 17, 95-121.

Constantinides, G.M. (1990): Habit Formation: A Resolution of the Equity Premium Puzzle. Journal of Political Economy 98, 519-43.

Frank, R.H.; R.M. Hutchens (1993) Wages, Seniority, and the Demand for Rising Consumption Profiles. Journal of Economic Behavior \& Organization 21, 251-276.

Grund, C. (2001): Der zwischenbetriebliche Arbeitsplatzwechsel - Determinanten, Konsequenzen und empirische Befunde für die Bundesrepublik Deutschland. München und Mering.

Hutchens, R.M. (1989): Seniority, Wages and Productivity: A Turbulent Decade. Journal of Economic Perspectives 3, 49-64.

Kahneman, D.; A. Tversky (1979): Prospect theory: An Analysis of Decision Under Risk. Econometrica 47, 263-291.

Kräkel, M. (1994): Frühstarteffekte in betrieblichen Karrieren. Zeitschrift für Personalforschung 8, 419-445.

Lazear, E. (1979): Why is there Mandatory Retirement?. Journal of Political Economy 87, 1261-84.

Markowitz, H. (1952): The Utility of Wealth. Journal of Political Economy 60, 151-158.

Matiaske, W.; T. Mellewigt (2001): Arbeitszufriedenheit: Quo vadis? Eine LängsschnittUntersuchung zu Determinanten und zur Dynamik von Arbeitszufriedenheit. Die Betriebswirtschaft 61, 7-24.

Pucik, V. (1991): Promotion Patterns in a Japanese Trading Company. Japanese Economic Studies 19, 37-55.

Rosenbaum, J.E. (1979): Tournament Mobility: Career Patterns in a Corporation. Administrative Science Quarterly 24, 220-241.

Tversky, A.; D. Kahneman (1991): Loss Aversion in Riskless Choice: A ReferenceDependent Model. Quarterly Journal of Economics 106, 1039-1061.

Wall, T.D.; C.W. Clegg; P.R. Jackson (1978): An Evaluation of the Job Characteristics Model. Journal of Occupational Psychology 51, 183-196. 


\section{IZA Discussion Papers}

\begin{tabular}{|c|c|c|c|c|}
\hline No. & Author(s) & Title & Area & Date \\
\hline 373 & S. J. Trejo & $\begin{array}{l}\text { Does the Statutory Overtime Premium } \\
\text { Discourage Long Workweeks? }\end{array}$ & 1 & $10 / 01$ \\
\hline 374 & $\begin{array}{l}\text { G. J. van den Berg } \\
\text { B. van der Klaauw }\end{array}$ & $\begin{array}{l}\text { Counseling and Monitoring of Unemployed } \\
\text { Workers: Theory and Evidence from a } \\
\text { Controlled Social Experiment }\end{array}$ & 6 & $10 / 01$ \\
\hline 375 & $\begin{array}{l}\text { J. A. Dunlevy } \\
\text { W. K. Hutchinson }\end{array}$ & $\begin{array}{l}\text { The Pro-Trade Effect of Immigration on } \\
\text { American Exports During the Late Nineteenth } \\
\text { and Early Twentieth Centuries }\end{array}$ & 1 & $10 / 01$ \\
\hline 376 & G. Corneo & Work and Television & 5 & $10 / 01$ \\
\hline 377 & S. J. Trejo & $\begin{array}{l}\text { Intergenerational Progress of Mexican-Origin } \\
\text { Workers in the U.S. Labor Market }\end{array}$ & 1 & $10 / 01$ \\
\hline 378 & $\begin{array}{l}\text { D. Clark } \\
\text { R. Fahr }\end{array}$ & $\begin{array}{l}\text { The Promise of Workplace Training for Non- } \\
\text { College-Bound Youth: Theory and Evidence } \\
\text { from German Apprenticeship }\end{array}$ & 1 & $10 / 01$ \\
\hline 379 & $\begin{array}{l}\text { H. Antecol } \\
\text { D. A. Cobb-Clark }\end{array}$ & $\begin{array}{l}\text { The Sexual Harassment of Female Active-Duty } \\
\text { Personnel: Effects on Job Satisfaction and } \\
\text { Intentions to Remain in the Military }\end{array}$ & 5 & $10 / 01$ \\
\hline 380 & M. Sattinger & $\begin{array}{l}\text { A Kaldor Matching Model of Real Wage } \\
\text { Declines }\end{array}$ & 7 & $10 / 01$ \\
\hline 381 & $\begin{array}{l}\text { J. T. Addison } \\
\text { P. Teixeira }\end{array}$ & The Economics of Employment Protection & 3 & $10 / 01$ \\
\hline 382 & L. Goerke & Tax Evasion in a Unionised Economy & 3 & $11 / 01$ \\
\hline 383 & $\begin{array}{l}\text { D. Blau } \\
\text { E. Tekin }\end{array}$ & $\begin{array}{l}\text { The Determinants and Consequences of Child } \\
\text { Care Subsidies for Single Mothers }\end{array}$ & 3 & $11 / 01$ \\
\hline 384 & $\begin{array}{l}\text { D. Acemoglu } \\
\text { J.-S. Pischke }\end{array}$ & Minimum Wages and On-the-Job Training & 1 & $11 / 01$ \\
\hline 385 & $\begin{array}{l}\text { A. Ichino } \\
\text { R. T. Riphahn }\end{array}$ & $\begin{array}{l}\text { The Effect of Employment Protection on Worker } \\
\text { Effort: A Comparison of Absenteeism During } \\
\text { and After Probation }\end{array}$ & 1 & $11 / 01$ \\
\hline 386 & $\begin{array}{l}\text { J. Wagner } \\
\text { C. Schnabel } \\
\text { A. Kölling }\end{array}$ & $\begin{array}{l}\text { Threshold Values in German Labor Law and Job } \\
\text { Dynamics in Small Firms: The Case of the } \\
\text { Disability Law }\end{array}$ & 3 & $11 / 01$ \\
\hline 387 & $\begin{array}{l}\text { C. Grund } \\
\text { D. Sliwka }\end{array}$ & $\begin{array}{l}\text { The Impact of Wage Increases on Job } \\
\text { Satisfaction - Empirical Evidence and } \\
\text { Theoretical Implications }\end{array}$ & 1 & $11 / 01$ \\
\hline
\end{tabular}

